\title{
Reader-Interest Classification: Concept and Terminology Historical Overview
}

\author{
Daniel Martínez-Ávila* and Rosa San Segundo** \\ */** Universidad Carlos III de Madrid, C/Madrid 12628903 Getafe (Madrid), Spain, \\ *<dmartine@bib.uc3m.es>,**<rsan@bib.uc3m.es>
}

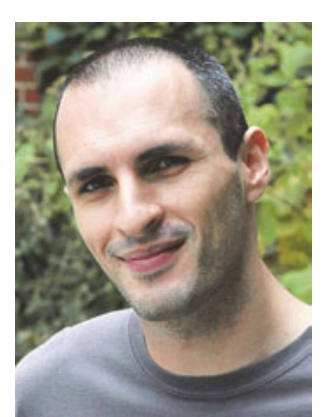

Daniel Martínez-Ávila is an assistant professor at Carlos III University of Madrid. He has a PhD in library and information science and a background in computer science. His research interests include classification systems, the application of poststructural and critical theories to information organization, and free software philosophy.

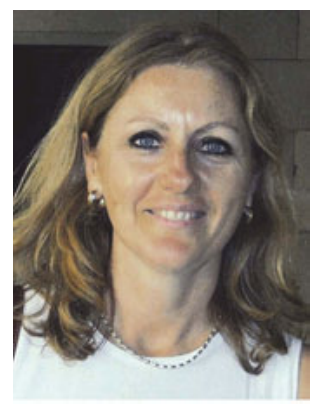

Rosa San Segundo has a PhD in information science and is a professor of classification and knowledge organization. She has been Secretary and Head of the Department of Information and Library Sciences at Carlos III University. She is President of the Spanish Chapter of ISKO, and a member of the UDC Consortium Advisory Board.

Martínez-Ávila, Daniel, and San Segundo, Rosa. Reader-Interest Classification: Concept and Terminology Historical Overview. Knowledge Organization. 40(2), 102-114. 69 references.

ABSTRACT: During the last century, the concept of reader-interest classifications and its related terminology have shown a well-established presence and commonly-agreed characteristics in the literature and other classification discourses. During the period 1952-1995, it was not unusual to find works, projects, and discourses using a common core of characteristics and terms to refer to a recognizable type of projects involving alternative classifications to the $D D C$ and other traditional practices in libraries. However, although similar projects and characteristics are being used until the present day, such as those of implementation of BISAC in public libraries, the use of reader-interest classification-related terms and references have drastically declined since 1995. The present work attempts to overview the concept and terminology of reader-interest classifications in a historical perspective emphasizing the transformation of the concept and its remaining characteristics in time.

Received 24-10-2012; Revised 31-12-2012; Accepted 12-14-2013

\subsection{Introduction}

Following a social view of concepts, "as socially negotiated meanings that should be identified by studying discourses rather than by studying individual users or a priori principles" (Hjørland 2009, 1530), reader-interest classifications might be considered a well-accepted concept during the last century according to the discourses of classifications, showing an agreed-upon core of characteristics in the literature and a recognizable, although somehow shifting, related terminology along the time. However, despite the presence of some of their characteristics and criticisms in some current classifications, the usage of some of its terminology and terms found in the readerinterest classification literature of the past seems to have declined or even disappeared from the current discourses.
The present study attempts to serve as an overview and analyze the history and transformation of the concept of reader-interest classification and its terminology, from the emergence of the concept to the present day.

\subsection{Reader-interest classification definition}

The term 'reader-interest classification' has been used to describe various approaches to library classification. In general, this umbrella term-and several of its nearsynonyms - refer to alternatives to traditional library systems such as the Dewey Decimal Classification (DDC), the Universal Decimal Classification (UDC), and the Library of Congress Classification (LCC). According to its advocates, reader-interest classification provides a more suitable arrangement for the reader because it gathers related 
terms scattered across the system and is more intuitive to use.

Within the literature, there are a great variety of terms that refer to this concept with minor variations; among them are 'alternative arrangement,' 'user-orientated arrangement,' 'categorized arrangement,' 'verbal arrangement,' 'bookstore arrangement,' 'stock categorization' (including the different regional spelling variations), 'readercentred classification' (used more recently by some Australian authors), 'two-tier arrangement,' 'integrated stock,' 'intensive use of paperbacks,' and 'subject departmentalism.' This variety of terminology and the regional differences of use were pointed out by Sapiie $(1995,144)$ :

There are nearly as many variations on the names given to reader-interest classification as there are instances of its use. Librarians in the U.S. have brought the plan into the modern age with the upto-date terms of merchandising, marketing and bookstore arrangement. In Britain, such terms as reader interest categories, categories or categorization are favored, but broad interest groups or user orientation are also used. Librarians create centers of interest in France and special interest comers in Japan. In Germany, immediate concern areas or alternative arrangement is used; in The Netherlands, broad subject arrangement, reader interest categories or topics of current interest; and in South Africa, the plan is called reader's interest classification.

In practice, many of these terms are used indistinctly in the literature or are studied together in a variety of case studies. However, 'reader-interest classification' seems to be the most representative of these terms. Examples of the relevance of the term 'reader-interest classification' may be found in its use as the authorized term in the $L i$ brary Literature \& Information Science Full Text bibliographic database thesaurus and also in its use by Ruth Rutzen, Home Reading Services Director at Detroit Public Library (in the first acknowledged case of a library applying a classification of these characteristics). According to, Rutzen (1952, 478):

the term reader interest classification is not a new library term. It has a familiar sound to those who have followed the literature on adult education in libraries. What is the purpose of the reader interest classification? It is yet another effort to make our service more meaningful and pertinent to the interests and needs of the general reader. What is it? It is a plan to arrange books on the shelf in terms of use and interest by the potential reader rather than strictly by subject content.
Paul Dunkin $(1969,124)$ expressed the reader-interest classification philosophy as follows: "RIC [reader-interest classifications] centers not on shelving books nor on logic, but on people and the fields of interest related to the everyday needs of the people." In another definition, Sharon Baker (1988a, 3) highlights the influence of commercial culture on this system, describing 'reader interest classification' as a "natural language classification similar to what the major bookstore chains use.” More recently, "reader interest classification" was defined in the Harrod's Librarian's Glossary of Terms Used in Librarianship, Documentation and the Book. Crafts as a "simple and broad classification intended to reflect the special interests of readers rather than the subject contents of books as such" (Prytherch 1990, 515). One of the most comprehensive and recent definitions of the concept, this time under the name 'Reader's Interest Classification,' was given by Mohinder Satija $(2004,182)$ in A Dictionary of Knowledge Organization:

A classification designed to serve the immediate needs of the targeted users. Such systems violate the filiatory sequence to bring together disparaged subjects needed by a user group. These are useful in mission oriented or multidisciplinary subjects. In a commerce college, e.g., it may be more pragmatic to place commercial law with commerce at 380. It is true to say that reader's interest classification adopted so far are not always satisfactory and sometimes correspond to ephemeral vogues. It reflects a middle level of ambition in knowledge organisation. It is a compromise between ad hoc classification and rigorously scientific classification.

Although the original reader-interest classification of the Detroit Public Library was later presented as a "readerinterest book arrangement," too (Detroit Public Library 1955), it should be noted that 'arrangement' —one of the main aspects of the concept-is not always mentioned in these definitions, as authors generally accept its importance; that is, it is assumed that the only way that readers can see their interests reflected in the library collection is through physical display and organization. Indeed, one of the most commonly expressed and well-accepted principles of reader-interest classifications is that the arrangement of books by categories has to be simple and selfexplanatory, minimizing the need to use the catalog or staff to find a specific book or subject (McCarthy 1982; Sapiie 1995). What is more, this arrangement has to be organized according to the reader's perspective and not that of the book, the library, or the librarian. Outside of the discipline of knowledge organization, reader-interest classifications were thus employed by the user-orientation movement in library and information science. 


\subsection{Reader-interest classifications as part of the user-orientation movement}

User orientation in libraries was defined by Den Reader as "any action by library staff which helps to make (and keep) the library relevant, busy, pleasant to use, and encourages self help" (Reader 1982, 35). Reader added that:

at the same time an attempt is made to keep a balance between the commonly-agreed areas of service (recreation/information/education). The guiding light is always to make stock as accessible as possible to readers, and to ask whether any of $\mathrm{Li}$ brarianship's 'sacred cows' are sacred simply to the profession, and are of no practical help to readers.

There are three important concepts within this definition that relate to reader-interest classifications: self-help, areas of service (or interest), and the questioning of librarianship's 'sacred cows,' i.e. traditional methods of classification and arrangement in libraries. Within the literature on reader-interest classification, this last point has been of particular interest to several authors. For Ainley and Totterdell, for instance, the rejection of traditional methods of classification and arrangement was one of the main raisons d'etre behind reader-interest classifications in libraries (Ainley and Totterdell 1982).

In general, it was claimed that traditional classification systems were not designed with the user in mind, but rather according to the interests of the collection or the staff or in the name of some academic dogma which was of no use to the readers-i.e., according to one of $\mathrm{Li}^{-}$ brarianship's 'sacred cows.' Elsewhere, Totterdell (1978, 13) also stated that "librarians may fear that the community's ideas of what the library's role should be may not coincide with theirs," making the opposition between librarians and "the community" even more evident. According to Den Reader $(1982,41)$ :

Librarians know how good their libraries are, but does the public? ... Without orientation towards its users, the library is in danger of dying, and where does that leave those who argue only about the necessity of maintaining standards? Standards, yes, but in a users' library, not a librarians' library!

As Reader pointed out, standards and standardization were not considered to be contrary to the concept of user-orientation; it was only the philosophy behind those traditional standards that was rejected.

Within the literature on reader-interest classification, it was quite common to contrast the traditional standards held by library/librarians (such as Dewey) with what were called users' standards. Such a contrast is neatly illustrated by comments made by Alan Sykes (1982, 383), librarian at Camden Library, after attending a "reader-interest classification course" in Surrey, another library adopting a reader-interest classification:

Above all, especially in the context of this course, we had to try to arrange stock in such a way that it reflected the mind of the reader and not the mind of the traditional ivory-tower, Dewey-obsessed, librarian. Since most readers were browsers, the best arrangement was probably by broad subject areas in short, a popular arrangement.

For Douglas Betts, principal librarian at Surrey County Libraries, there was a danger of developing reader-interest categories which accounted for the needs of the librarian instead of the user, or in other words, of following the same process applied in traditional classifications: "lists (sometimes helpful) of favoured topics and fiction genres appear in some surveys, although the categories tend to be the librarian's, not the reader's" (Betts 1982, 65). However, Betts regarded the categorization system as only a small part of a larger plan towards a more user-orientated service- one which combined the physical re-presentation of public libraries and a systematic demand-related approach to stock logistics and books selection (Betts 1982).

Opposition to the use of the DDC and UDC has extended to the recent implementations of bookstore schemes in libraries (Martínez-Ávila, Olson, and Kipp 2012a; Martínez-Ávila, Kipp, and Olson 2012b). However, it is arguable that, despite two decades of the readerinterest movement, satisfactory alternatives have yet to be developed. As pointed out by Birger Hjørland, part of the problem is one of paradigms; that the 'bibliographic paradigm' is sometimes wrongly assimilated to the 'positivist view.' Such a perspective might also have ramifications for the debate concerning cases of reader-interest classification and the philosophy that informs them. Hjørland (2007, 2) writes:

It seems as if the term 'the bibliographical paradigm' has only been used negatively as a contrast of something better. In this context it has been suggested that it is a part of 'the systems-oriented perspective' (or 'physical paradigm') in library and information science, which in the received view, is opposed to user-oriented paradigms.

In the context of reader-interest classification, the systemoriented perspective would be represented by traditional schemes and views such as Dewey; in the user-oriented paradigms, on the other hand, the "something better" 
would correspond to reader-interest classifications. In a different context, another example of assimilation of the 'bibliographic paradigm' to positivism and contrast of something else can be found in San Segundo (2004).

However, it cannot be assumed that a proper locational view - the way facets are displayed within the system-depends on objective definitions of potential use, meaning, and mental activity. Even when users (in opposition to librarians or information scientists) are claimed to be the guiding force in the development of the system, it should also be recognized that there may be different groups of users who would benefit from different sets of facet development. Despite, or maybe because of, the arguably unfair assimilation implied in the use of the singular term "reader" or "user" (similiar to the discussion of the singular term "public" in other knowledge organization systems discussed in, for instance, Olson 1997 and Olson and Schlegl 2001), the existence of several groups of users is usually recognized among reader-interest classification practitioners. Indeed, the inclusion of those users with a high-grade of expertise (as well as classificationists) is considered a handicap for the overall outcome of the system. In this vein, another key opposition in the reader-interest classification literature is the division between purposive and non-purposive reader-a distinction usually made to justify the convenience of this type of classification for the (non-purposive) public. Such an approach is reflected in various studies, such as Jones (1971), Donbroski (1980), Ainley and Totterdell (1982), Betts (1982), and Morson and Perry (1982).

\subsection{Definition of purposive reader and non-purposive reader}

As in the case of the term 'reader-interest classification,' the terms 'purposive reader' and 'non-purposive reader' were not always used exclusively within the literature. Near synonyms of 'non-purposive reader' found in the literature include 'non-specific reader,' 'casual reader,' 'plan-less reader,' and 'browser.' Some near synonyms of 'purposive reader' in the literature include 'specific reader,' 'systematic reader,' 'subject-orientated reader,' and, in one case, there are some more general and ambiguous terms such as 'scholar' and 'student' (Ørvig 1955, 224).

In general, a purposive reader is defined as a searcher who accesses a book in the shelves, knows exactly where it is located, after using an indexing tool that he or she knows well (such as a library classification system). A nonpurposive reader, on the other hand, is usually defined as a searcher with no specific title in mind and who does not necessarily have any training on the library classification system or library use. Sometimes, the definition of nonpurposive readers also includes what Mary Ørvig called the non-inquirer reader-one who never approaches the librarian for help and does not want to be talked to. This kind of reader is usually characterized as a browser since sometimes his/her autonomy of use vs. library training does not allow the reader any other main way to access to the information. Because of this, 'browser' is one of the most common near-synonyms of 'non-purposive reader' to be found within the context of reader-interest classification-a term that emphasizes how access is acquired rather than what type of access is preferred.

As suggested above, the purposive reader is usually defined as a reader who is more familiar with the library and how the traditional library classification works. This is not usually the case with the non-purposive reader-as Ørvig states, "the planless reader and the browser, who in fact constitute great percentage of the public library clientele, have little or no use for the perfect catalogue" (Ørvig 1955, 224). Traditional library classifications and catalogs are therefore considered to be more adequate for purposive readers (who are in the minority), while nonpurposive users (who are in the majority) are assumed to have access to the materials by browsing. The distinction between purposive and non-purposive readers is thus sometimes defined by the relationship between access methods and the knowledge of the system.

On the other hand, the traditional approach is considered to fail to meet the needs of the real public, with some authors arguing that the majority of users in most reader-interest cases are browsers or non-purposive readers (Ainley and Totterdell 1982, 121). A reader interest perspective thus justifies a non-purposive friendly scheme which is able to meet the majority's needs, as opposed to the traditional practices represented by the $D D C$ that only meet the librarian's design needs. Authors in favor of reader-interest classification generally assume that traditional library classifications, such as Dewey, fit the purposive readers' information-seeking patterns because they provide a specific location for a specific title. Once the user's information need is translated into a query through the catalog, the exact location of the title is provided by the call number and by following a systematic arrangement of the books on the shelves.

Yet, the assumption that the needs of the purposive reader are best met by Dewey or any other traditional library system also supposes that the needs of the nonpurposive reader are best met by alternative classification systems. These alternative classifications were given the term reader-interest classification following the assimilation of non-purposive reader's interests to reader interests (as a singular and homogeneous group) and the assumption that this group was in the majority. One of the problems here would be the attempt to characterize the binary purposive/non-purposive reader as a dichotomy. Theoretically, 
any kind of reader can access information equally by browsing or by direct access, even if the majority of access or preference is realized by only one method. However, here it should also be noted that if the main characteristic of the distinction between purposive and non-purposive readers is the level of knowledge of the system - and not the method of access- then these groups would in effect be mutually exclusive. But even in this case, the distinction should be made between Dewey users and non-Dewey users, instead of browsers and Dewey users - it is reasonable to think that every reader is able to browse without training although not every reader is able to use Dewey without training. More recently, outside the context of the readerinterest classification, other authors have studied the distinction between purposive readers and non-purposive readers such as Ágústa Pálsdóttir, who has distinguished between purposive information seeking and information encountering (Pálsdóttir 2010).

\subsection{History and origins of reader-interest classifications}

Thus, the origins of reader-interest classifications are linked to the inadequacy of traditional library classification systems to primarily cater to that majority of nonpurposive readers, "the reader." However, the origin of the reader-interest classification concept in the timeline is not completely obvious according to this criterion, since, as pointed out before, the term reader-interest classification covers a wide range of concepts that display some common characteristics not all of them related to the classification system itself. While these concepts were usually practiced by a single-but geographically dispersed-movement, it is somewhat difficult to establish a unique time line for reader-interest classification as a whole. Indeed, the variety of concepts within the term, make it difficult to trace their emergence-that is from previous forms to a stage that could be "considered" to be a reader-interest classification (according to its characteristics). As such, it is not only a challenge to identify the origin of reader-interest classifications as a movement, but also to identify the origin of some of the individual terms covered by the umbrella term.

One example of this problem is the concept 'subject departmentalism'- the organization of materials separated by subject areas - that was at one point included in reader-interest classification movement. According to Michael A. Overington, the first experiments with subject departmentalism in public libraries were made in Chicago in 1893 but were first fully developed in Cleveland in 1925 and in Los Angeles in 1926 (Overington 1979). Considered as a whole, this concept might only be considered a reader-interest classification at the exact point in which it was referred in the reader-interest classification literature. Outside of this moment, the concept of subject departmentalism changed so rapidly that it could not really be considered a reader-interest classification or even related to any type of library classification. It could be argued that the only point in common between this concept and the reader-interest classification movement would be how both apply a different scheme for the useroriented divisions. However, as with the case of the 'twotier arrangement,' the idea of splitting the collection into several departments without any "user-oriented" section remains beyond the parameters of this study.

It is commonly agreed that reader-interest classifications - as alternatives to the established and so-called "non-friendly" standards such as Dewey-were first used in the late 1930s at the Detroit Public Library in the United States. Reader-interest classification thus first came to light some 60 years after the publication of the first edition of the Dewey Decimal Classification (then called A Classification and Subject Index for Cataloguing and Arranging Books and Pamphlets of a Library) and only few years after the publication of the second edition of its European adaptation, called for the first time "Classification Décimale Universelle"-Universal Decimal Classification. Readerinterest classifications therefore arrived just as the UDC was being promoted as a universal tool for classification, and the DDC in the United States came to be regarded as the most adequate standard for libraries.

This second edition of the UDC, published in the years 1927-1933, emphasized the "universal" nature and purpose of the library classification as a one-fits-all scheme-to the extent that its competitors sometimes felt that their share of the market was under threat. On the other hand, since the first edition of the UDC was originally intended as a tool for Otlet and La Fontaine's "Universal Bibliographic Repertory," it was commonly and mistakenly believed or promoted by some librarians that the UDC could be only useful for the organization of bibliographic materials, while the $D D C$ would be more useful for libraries.

As Indian librarian and theoretician Ranganathan pointed out, every adaptation that departed (or evolved) from the "one good custom" that is DDC was also branded as "heresy" (Ranganathan 1967, 528). Indeed, at the time that these observations were made, the division between "General classification vs. Specialist classification," i.e., the division between classifications for libraries and classifications for knowledge and the sciences, became a subject of dispute. The UDC, Bliss Classification, and Ranganathan's Colon Classification (along with every other classification that was either more faceted or considered more complex than the $D D C$ ) were accused by advocates of the $D D C$ of not being adequate for public libraries - in other words, of being specialist classifica- 
tions. That being said, the division between specialist and general classification were very different from later arguments that established a connection between general classifications $(D D C)$ and purposive readers, and between specialist classifications (adaptations or alternative classifications) and casual readers.

In fact, while library classification practitioners seemed to be divided between DDC adepts and "changers," it is also true that library classifications seemed to change along either theoretical or practical lines in libraries (although it has to be acknowledged that both views contain theoretical and practical aspects).

It might also be argued that library classification practitioners were divided according to their attitude towards change. Those in favor of DDC, naturally enough, militated against the faceted nature and complexity of the new schemes (such as UDC, Bliss or Colon Classification). "Changers," on the other hand, sought to modify the $D D C$ but never actually made claims against the universal stance of classifications. According to Ranganathan, disagreement between the two groups centered on concerns over the inadequate foundation of old schemes, the notational plane, minority interests (and how multiple facet orders could be useful in different contexts), overly hasty solutions, and the non-recognition of class number as a proper name (Ranganathan 1967, 529).

Ironically, some of the arguments employed by those in favor of $D D C$ were also used by a more recent group of "changers"-pro-reader interest classificationsagainst the DDC. This group was associated with the practical transformation of library classifications-most systems, after all, were developed on the basis of observation and daily experience of library users' needs.

All cases were also later influenced by previous experiences of other libraries and other reader-interest classification cases (such knowledge mainly being transferred via mouth-to-mouth, professional courses, or articles in professional journals). However, if reader interest classifications followed a genealogy or transformation process, we have to decide upon the moment in which this concept emerged as the predecessor of future moments, i.e., we have to decide upon the first properly named example of reader interest classification. And in the case of the readerinterest classifications, this point is commonly agreed to be the Detroit Public Library in 1941 (Rutzen 1952, 479; Ørvig 1955, 224; Ainley and Totterdell 1982, 9).

\subsection{The first reader-interest classification: Detroit Public Library}

The roots of the first reader-interest classification, implemented at the Detroit Public Library, date to 1936, when Ralph A. Ulverling, then associate librarian at De- troit Public Library, came up with the idea of a classification scheme that offered an alternative to the classification of subjects represented in the DDC. In his proposal, Ulvering stated, "For some time I have wondered whether our popular book lending service as organized on traditional lines is pointed directly enough toward our service objectives; that is, whether the organization of our circulating units is adapted to the function we are trying to fulfill” (Rutzen 1952, 479). Others would later echo this as "[to] classify not by subject but by patrons' reading inclinations" (Woodford 1965, 119).

A few years later, when Ulverling became a full librarian at Detroit, his idea was partially adopted in a pilot experiment at the Main Library in 1941, in what was called the "Browsers' Alcove" in the Open Shelf Room at the Main Library. The adoption of this experiment is considered to be the first time that reader-interest classification was applied. The original experiment at Detroit was applied to a collection of about three thousand books and was composed by the following headings: Background Reading (Classics, Art, Music, Belles Lettres), Everyman's Affairs (Current National Problems), World Today-World Tomorrow (The International Scene), Personal LivingHome and Family (Family Relations, Maintenance of House and home), Work and Play (Crafts and Hobbies), Adventure (Mostly Travel, geographical and scientific exploration), Bright Side (The Light, the Gay, the Humorous), Industrial Era (Men, Machines, Mass Production and Its Effects), Human Experience (Biography, and Some Types of Travel and History), Other Places (Travel), and Exploring Science (Application of Modern Science).

The public responded positively to this test, and the entire bookmobile service was rearranged according to this system in 1945. From December 1948, the system was extended to both old and new branches in Detroit, and, by 1952, the newly established branches of Edison, Wilder, and Hubbard had been categorized following the scheme. By 1952, some of the headings included in the final scheme were: Background Reading (includes Philosophy, History, Great books, Belles Lettres, and classics in all fields, "arranged in one alphabet by author"), Current Affairs (Foreign Relations, National Problems, Labor and Capital, March of Science), Family Life (Marriage and Family, Child Care, Health, Country Living), Your Home (Planning, Decoration, Management), The Arts (Painting and Sculpture, Theater, Poetry), and People and Places (Our Neighbors, In Many Lands) (Rutzen 1952, 480). Once this first attempt was considered successful, the scheme was expanded to 12 headings and applied to other branches. Four collections which moved into new buildings - the Elisabeth Knapp, Sherwood Forest, Lincoln, Jefferson and Jessie Chase branches-were completely classified according to the system, and several old 
branches were partially reclassified along the same lines (Rutzen 1952, 479).

By 1955, the final version of the scheme was a combination of 14 "subject sections" (categories of interest for the browser) and "information sections" with fields such as "content," "alternatives," and "purpose." Each section was subdivided into subheadings and represented by an alpha-numerical notation. Subject sections were intended to serve readers with specific needs, while information sections contained factual material and textbooks for answering specific questions. This version of the scheme was proudly made public by the Detroit Public Library (1955). In the introduction, and subsequent editions and publications (e.g. Rutzen 1959, 55), the system was presented as follows:

This is a book arrangement planned to fit the needs and uses of the greatest number of people. It recognizes the variety of reasons prompting people to come to the library. It is not a classification of the fields of knowledge but a shelving arrangement based on broad areas of interest which relate themselves to the everyday needs of people. These broad areas have been designated as interest categories. They are subdivided by a varying number of subheadings, depending on the type of category and the size of the collection. Some categories are browsing sections for the general reader; others are subject groupings aimed at a particular use by the reader.

At this time, there was no theoretical division between casual readers and purposive readers, although Dewey was retained in most old branches that adopted the new system and was eventually dropped in smaller collections. There was thus a well-established belief that there was only one kind of reader and that browsing would be improved by meeting all readers' specific needs. On the other hand, there were multiple reasons why Dewey was retained in many of the collections: first, catalog cards were produced at the central library, carrying the Dewey number; second, all experiments could be undone if results were not considered positive (a "certain safeguard if our experiment should prove not to be workable" (Rutzen 1952, 481)); third, it was difficult to have the collections rearranged manually. This was also a problem for the different versions of the scheme, and something that somehow contributed to the idea that reader-interest classifications were only adequate for smaller collections.

Eventually the scheme in Detroit was dropped due to the lack of universalization and centralization, which meant a waste of resources (Ainley and Totterdell 1982, 9); this was reportedly related to the cumbersome and expensive need to reclassify and relocate materials (Hyman 1982,
67). Its legacy however was significant: not only were similar schemes adopted in other library systems in the United States (such as the Boston Public Library), but they were also presented to a European audience (Ørvig 1955).

While it is commonly accepted that reader-interest classification is a unique concept, Rutzen claimed that some of the ideas for the Detroit Public Library project came from library and information science theorists such as Douglas Waples (1937), Lowell Martin (1940), and John Chancellor (who in 1930 briefly outlined a scheme for shelving books by reader interest) (Rutzen 1952, 479; Rutzen 1959, 55). The project also drew upon experiences of librarians in the United States which could be considered as the direct precursors to the first reader-interest classification. Among these librarians was Ralph Munn who established the Public Affairs Room: "It is our hope that we can present books dealing with public questions so effectively that even the uninterested reader will be attracted to them" (Munn cited by Rutzen 1952, 479). There were also librarians such as Helen D. Marvin from West Park Branch in Cleveland Public Library who talked about the attention paid to the reader-interest area Home and Family Living. In words of Rutzen, "Our experiment seems not to be so different in ideas as in the extent to which we are applying them." The practical influence of reader-interest classification led to its transmission from library to library and still remains among its agreed characteristics.

\subsection{Transformation of reader-interest classifications during the 1970s: the user-centered revolution peak}

Following the experience at the Detroit Public Library, reader-interest classifications became particularly popular with many public libraries during the late 1970s. In part, this can be explained by the fact that the user-orientation movement reached its peak at this time-reflected by the fact that it started to gain acceptance within library and information science and information organization around 1970, as pointed out by Hjørland $(2007,3)$ and Nahl (1996; 2003).

Another factor in their popularity might also have been a general desire at that time to experiment with change; the oil crisis of 1973 and the subsequent recession meant that libraries were forced to seek out alternative sources of funding and to develop innovative projects and commercial-oriented practices in order to maximize their resources. As a consequence, some libraries started to look towards bookstores and commercial practices for solutions and were thus influenced by some of their information organization practices (and in some cases these libraries ended up adopting some of these practices). 
The relationship between the user-centered movement and the development of library standards has been recently studied by Gretchen L. Hoffman (2009, 633). According to Hoffman, library and information science standards started to move toward the user-centered paradigm in research and practice with contributions from researchers such as Paisley (1968), Allen (1969), and Zweizig (1976) shifting the paradigm within library and information science from systems and standards to users.

This interest in user-centered practices and theories also affected the way that libraries were physically organized and a wide range of practices and arrangements were embraced under the reader-interest or user-centered umbrella. Among the main studies conducted on library classification from a user-centered perspective were works by Groombridge (1964), Luckham (1971), and Taylor and Johnson (1973) (see Ainley and Totterdell 1982). As pointed out by Ainley and Totterdell, most of these works — and those similar to them-mainly focused on non-fiction collections.

One of the first proponents of reader-interest classification in the UK is considered to be Archibald William McClellan, Chief Librarian of Tottenham. From 1949 to 1970, McClellan studied a wide range of concepts related to the social and pragmatic role of libraries within society and the way libraries could serve the community. One of his central concerns was the reader, and McClellan committed himself to finding the best way to arrange the collection in order to meet the reader's interests (McClellan 1973), with a particular focus on the integration of stock and the division of the collection (or two-tier arrangement). In subsequent years, the experiment conducted by Tottenham library with reader-interest arrangements was an important source of inspiration for many other libraries all across the country.

\subsection{Decay of non-fiction reader-interest classifications during the 1980s and 1990s}

During the 1980s, there was a loss of interest among public libraries in applying reader-interest classifications to non-fiction. Despite this, the philosophy behind the reader-interest classification movement was still considered relevant and debate continued as to the validity and adequacy of Dewey. One example of this debate can be found on Arthur Maltby and Ross Trotters' interesting discussion in the Catalogue and Index journal of 1984 on the adequacy of Dewey and on reader-interest classifications as possible solutions to problems faced by contemporary libraries ("Dewey as an Asset" (Trotter 1984) and “Dewey Decimal Classification: a Liability?” (Maltby 1984)).

While both authors recognized that Dewey might not be totally adequate for libraries, neither did they consider reader-interest classifications to be the best of alternatives. In defending Dewey, Trotter $(1984,1)$ stated that:

The recent obsession with 'reader interest treatment' is at base nothing more than broad enumerative classification taken to extremes. All this approach does is to set up a small number of very broad disciplines, and then to ignore, more or less, any principles of subdivision within them. I personally feel that this is something of a cop-out, leaving the reader with most of the work of locating the sort of material he or she requires. A regular classification, with principles of division and subdivision, and backed by a good alphabetical index, is to my mind far superior.

In addition, Trotter $(1984,3)$ also claimed that the only possible challenger to Dewey might have been Bliss Classification 2 (BC2) but that this had failed: "I also feel that even with these faults Dewey offers a better deal than any alternative - and that includes reader interest arrangement. The only possible challenge is Bliss 2 but I doubt it."

On the other hand, Arthur Maltby, who was more critical of the $D D C$, also expressed his disappointment in the BC2. Concerning the reader-interest classifications, Maltby (1984, 5) stated, "One public library alternative has been reader interest arrangement, which has had a mixed public reception and varying degrees of success ... there are some Scottish examples of the phenomenon, for instance in Falkirk District (Bo'ness), Glasgow (Castlemilk) and Renfrew District (Ferguslie Park). Headings in the last name include "Sexy Books." On the other hand, Maltby had also praised Ainley and Totterdell's work on reader-interest classifications-a recognition that surprised both of these authors because of his work on classification.

Some commentators have however argued that the retrospective classification and the degree of training that systems such as BC2 require could impede their adoption. As Hjørland $(2007,8)$ pointed out:

It is somewhat ironic than the most used tool for classification in libraries today is the DDC first published 1876. More that hundred years of research and the development of other kinds of knowledge organizing systems has not resulted in making $D D C$ obsolete. For example, the BC2 is generally considered theoretically more advanced, but has difficulties being used in practice. The main reason may be that most of the English-language books bought by a given library are pre-classified with the DDC by the Library of Congress. Another reason may be that they are not considered user-friendly because 
users have to learn certain principles. It is, however, thought provoking that classification systems developed later and generally thought more advanced are not able to compete efficiently.

In some ways, Hjørland's observations on the BC2 might also apply to reader-interest classification, given that the problem of reclassification concerns all systems. Although the main problem with the adoption of systems such as BC2 might be one of document reclassification, the argument of user-friendliness seems to have been the decisive factor among libraries in either adopting new schemes or continuing with some sort of old system (indeed, in reader-interest classifications, user-friendliness was often the only factor involved in the decision).

Although it suffered a decline during the 1980s, nonfiction reader-interest classification was still practiced in some libraries during the first half of the 1990s. Among them were the De Beauvoir Junior School Library in the UK (Bridgwater 1990) and the Glasgow City libraries (Miller 1992) while other instances can be found in Jacquelyn Sapiie's work (one of the very last bibliographic retrospectives on reader-interest classifications found in the literature) (Sapiie 1995). Although De Beauvoir Junior School Library pointed out that the previous experience of Brent and Camden libraries in the 1980s had influenced their own experiment in reader-interest classification, their interest in the advantages of this system were practically confined to the children's section, leaving the adult section with a shadow of a system that had been designed to provide for the whole collection: "Readers will be aware that such schemes have been very successful, particularly in the organisation of children's libraries (though many adult users also express relief at the introduction of an easier system)" (Bridgwater 1990, 53).

The De Beauvoir and Glasgow City libraries might be considered two of the very last non-fiction readerinterest classifications cases per se reported in the literature, the former denominated under the system of broad categories (or subject categories), and the latter as an alternative arrangement. In some ways both cases were the last of an era in which the concept of reader-interest classification captured the attention of many librarians.

\subsection{Rise of the reader-interest classifications of fiction and bookstore practices since the 1980s}

Coinciding with the popularity shifting from non-fiction reader-interest classification projects to fiction readerinterest classification projects, a new terminology related to bookstore and commercial practices emerged in library classifications. As Richard Maker (2008a, 171) points out, the concept of fiction categorization was initially " bor- rowed' from a bookstore model because it is thought people prefer to browse and choose books by genre rather than alphabetically by author." In practice, the concept has been noticeable popular in the UK and the Eastern States of Australia since the late 1980's (Maker 2008b). A quick survey of the literature reflects the development of this popularity; initially, fiction categorization was either secondary or non-existent in the readerinterest classification experiments (Sawbridge and Favret 1982; Wijland 1985) or was given the same importance as non-fiction (Augenanger 1981; Venter 1984; Sivulich 1989). The central role given to fiction categorization can be seen in the works of Harrel (1985), Baker and Shepherd (1987), Borden (1987), Langhorne (1987), Baker (1988b), Kellum (1989), McGrady (1990), Scott (1995), Saricks (1997, 2006), and Scilken (1998).

It is perhaps worth emphasizing that the increased popularity of the concept during the 1980 s and 1990 s coincided with the declining interest in reader-interest classification of non-fiction. The concept of reader-interest classification kept on developing at its own pace during these decades. As Sapiie $(1995,143)$ pointed out, "recent literature since 1980 indicates that there is some variety of the schemes in use today in the United States, Britain and many other countries as an alternative to the major classification systems." However, it should be noticed that the term reader-interest classification was also abandoned for a more commercially orientated vocabulary as new terms and ideas from bookstores and commercial spheres became increasingly popular in the United States. One example of this trend can be found in Mary Jo Langhorne's work, where bookstore approaches in libraries were compared with previous reader-interest experiments in the UK in the areas of fiction and non-fiction categorization, labeling and signage, visibility, and physical location and display (Langhorne 1987). Although bookstore techniques seemed to be a more commercial and more appealing concept in the 1990s than 'readerinterest classification' or 'alternative arrangement,' it was virtually alike in all but name and the new techniques did not add anything new to the previous concepts.

Relabeling of the reader-interest concept as a "bookstore (bookshop) approach" did not only take place in the United States in the 1990s but also in countries that followed the British tradition during the 2000s, such as the United Kingdom itself and Australia. While these approaches had many characteristics in common with the reader-interest classifications (which had been very popular during the previous decades in some of these countries), rarely did they include the terms 'bookstore classifications' or 'classifications.'

For instance, the 2002 Audit Commission's "Building Better Library Services" report in the UK indicated several 
aspects that libraries could improve if they adopted bookstores practices (Audit Commission 2002). Although the Audit Commission's report did not mention library classification systems, it applied arguments that were almost identical to those employed more than 20 years earlier during the reader-interest experiments. While the term 'readerinterest' was completely omitted from the report, references to having "the user at the center" are clearly reminiscent of the user-centered movement days. In fact, the Audit Commission report borrowed several ideas from the user-centered movement in order to describe their own vision of the ideal library (Audit Commission 2002, 25):

Services need to be designed with the user at the centre-built around a realisation that people use their services out of choice-and a clear understanding of the services and experience people want: 1. Libraries need to provide the books and information services people want-or people will have no reason to come. 2 . These services need to be easily accessible, in terms of opening times and location — or many potential users may be put off using them. 3. They need to provide a positive and welcoming experience for the user, in terms of the environment and how easy services are to use-or people will choose to go elsewhere. 4. And, people need to be aware of the full range of services on offer and how they can get them.

Other interesting concepts used in the Audit Report were the terms 'reader development' and 'reader development schemes.' These terms basically coincided with the practical applications of reader-interest classifications to the collection development and stock control. This latter aspect was also pointed out by many reader-interest classification advocates, such as Ainley and Totterdell (1982), as being one of the main advantages of reader-interest classifications in the past. It could be argued that these advantages seem to have remained valid over time.

\subsection{Current cases of implementation of BISAC in public libraries as new cases of reader-interest classifications?}

Regarding non-fiction, one further step in the concept of reader-interest classification might arguably be the recent experiments of US public libraries adopting the scheme of the American book industry, BISAC, for the classification of the collection. Since the second half of the 2000's, several public libraries in the United States have been experimenting with BISAC as an alternative classification system to Dewey for non-fiction. These kinds of experiments gained major attention by the media mainly in 2007, when Perry Branch Library in Maricopa County (Arizona) was presented in the literature as the first case of Dewey-BISAC switching in US public libraries.

On May 30, 2007, The Arizona Republic announced that Perry Branch Library located in the town of Gilbert in the Maricopa County Library District would be "the first public library in the nation whose entire collection was categorized without the Dewey Decimal Classification System" (Wingett 2007). Despite it not being exactly true that it was the first library in the US to drop Dewey, Perry Branch Library did mark a milestone in the field as the first public library in the US to adopt the book industry standard BISAC instead of Dewey as the classification system for organizing the collection.

Perry Branch Library opened in June 2007, and, for the organization of its 24,000-item collection, 50 BISAC headings were used instead of Dewey. This idea had been previously devised by director Harry Courtright in 2005 and was implemented in 2007 by adult services coordinator Marshall Shore with the opening of the Perry Branch, although Nanci Hill, Head of Readers' Services at the Nevins Memorial Library in Methuen, Massachusetts, stated that the beginning of the concept was a pilot plan in two libraries in Delaware County (Pa.) in 1988 (Hill 2010). According to Amy Wang (2009) of The Arizona Republic, the conversion plan for the system in the Perry Branch took nearly five years, although county officials say that by 2009 it only took from one to two months to make a library Dewey-less.

After this case, several other libraries in the United States and abroad have looked to Maricopa as a source of inspiration for the remodeling and new opening projects of their systems. As well, they started to consider BISAC and other bookstore-like techniques as a good alternative to the traditional practices in knowledge organization. Despite the omission of every reference to the old and failed reader-interest classification projects in the discourses of adoption of BISAC in libraries, with the exception of a brief mention in an editorial of School Library Journal (Kenney 2007), these cases of DDC-BISAC switching for non-fiction have also been studied as new cases of readerinterest classifications (Martínez-Ávila 2012).

\subsection{Conclusions}

In accepting that the concept and terminology of readerinterest classifications has transformed and changed over time, despite its variations, it still shows an agreed-upon core of characteristics shaping its meaning and allowing its conceptualization. As pointed out by Martínez-Ávila (2012), some of these characteristics of reader-interest classifications include: dropping traditional practices like Dewey; using alphabetical/natural language categories for 
the physical arrangement of materials; organizing and representing knowledge according to topics of interest instead of academic disciplines; carrying out the classification process at the book selection service instead of the cataloging service and all that difference implies; and accepting the influence of bookstore practices in such diverse aspects as guiding, signage, and display. Among the alleged advantages of reader-interest classifications projects are: meeting the user's needs (by gathering together materials of interest that had been previously dispersed by Dewey), reversibility of the experiments, the possibility of putting different changes and innovations into effect at one time (although sometimes these are impossible to separate or even identify clearly and not always related to the classification scheme), the cost saving (including aspects such as the acquisition of cheap formats), greater shelving flexibility, improved adequacy for browsing, increase in circulation, and a good method of identification in the most demanded areas for stock control purposes. Finally, some of the detected shortcomings of reader-interest classifications include: problems of reclassification according to a non-standardized scheme, inadequacy of reader-interest classifications for all sized libraries (specifically for bigger libraries), the creation of other "distributed relatives" when rearranging knowledge according to topics of interest, the possibility of low quality in the nature of the categories reflecting readers' interests, and a lack of centralization and universalization, which is widely regarded as the main cause that led the first reader-interest classification cases to fail. As for the terminology, historically, there has not been a single, unified terminology on the concept of reader-interest classification in the literature. During the different stages of the concept its terminology was changed from the original term "reader-interest classification" used in the case of the Detroit Public Library (and first expressed in the literature in 1952) to the more commercial oriented terminology of the 1990s and after. However, although the terminology and some of the reader-interest classification features have varied according to the literature during the period of 1952-1995, the concept has also kept a core of common and agreed-upon characteristics, alleged advantages and shortcomings throughout this time, i.e. there is a continuity in the discursive formations that allow reader-interest classification to be discussed as a concept.

\section{References}

Ainley, Patricia and Totterdell, Barry. 1982. Alternative arrangement: new approaches to public library stock. London: Association of Assistant Librarians.

Audit Commission. 2002. Building better library services. Audit Commission. Available http://www.audit-commission.
gov.uk/SiteCollectionDocuments/AuditCommission Reports/NationalStudies/ACKLibraries.pdf (Accessed 20 August, 2010).

Augenanger, Petra. 1981. Der 'nahbereich' aus sicht des benutzers [The 'immediate concern' area from the user's point of view]. Buch und bibliotek 33 Jan.: 46-8.

Baker, Sharon L. 1988a. Designing libraries to meet the needs of browsers. The unabashed librarian 67: 3-5.

Baker, Sharon L. 1988b. Fiction classification schemes: an experiment to increase use. Public libraries 26 no. 3: 75-7.

Baker, Sharon L. and Shepherd, Gay W. 1987. Fiction classification schemes: the principles behind them and their success. Reference quarterly 27: 245-51.

Betts, Douglas. 1982. Reader interest categories in Surrey. In Ainley, Patricia and Totterdell, Barry, eds., Alternative arrangement: new approaches to public libraries stock. London: Association of Assistant Librarians, pp. 60-77.

Borden, William Alanson. 1987. On classifying fiction. The unabashed librarian 63: 25-6.

Bridgwater, Sue. 1990. Out of the doldrums and into the curriculum: De Beauvoir Junior School Library. The school librarian 38: 53-4.

Detroit Public Library. 1955. The reader interest book arrangement in the Detroit Public Library. Detroit: Home Reading Services, Detroit Public Library.

Donbroski, Lyn. 1980. Life without Dewey. Catalogue \& index 57 Summer: 3-6.

Dunkin, Paul S. 1969. Cataloging USA. Chicago: American Library Association.

Groombridge, Brian. 1964. The Londoner and his library. London: Research Institute for Consumer Affairs.

Harrel, Gael. 1985. The classification and organization of adult fiction in large American public libraries. Public libraries 24 no. 1: 13-4.

Hill, Nanci Milone. 2010. Dewey or don't we? Public libraries 49 no. 4: 14-20.

Hjørland, Birger. 2007. Arguments for 'the bibliographical paradigm.' Some thoughts inspired by the New English Edition of the UDC. Information Research 12(4) paper colis06. Available at http://InformationR.net/ ir/12-4/colis06.html (Accessed 11 March, 2011).

Hjørland, Birger. 2009. Concept theory. Journal of the American Society for Information Science and Technology 60: 1519-36.

Hoffman, Gretchen L. 2009. Meeting users' needs in cataloging: what is the right thing to do? Cataloging \& classification quarterly 47 no. 7: 631-41.

Hyman, Richard Joseph. 1982. Shelf access in libraries. Chicago: American Library Association.

Jones, Ken H. 1971. Towards a re-interpretation of public library purpose. New library world 73 no. 3: 76-82.

Kellum, Debra. 1989. Fiction separation. The unabashed librarian 71: 3-4. 
Kenney, Brian. 2007. Desert storm. School library journal 53 no. 8: 9 .

Langhorne, Mary Jo. 1987. Marketing books in the school library. School library journal 33 no. 5: 31-33.

Luckham, Bryan. 1971. The library in society: a study of the public library in an urban setting. London: Library Association.

Maker, Richard. 2008a. Finding what you're looking for a reader-centred approach to the classification of adult fiction in public libraries. The Australian library journal 57: 169-77.

Maker, Richard. 2008b. Reader centred classification of adult fiction in public libraries. Australasian public libraries and information services 21: 168-71.

Maltby, Arthur. 1984. Dewey Decimal Classification: a liability. Catalogue and index 72: 4-5.

Martin, Lowell A. 1940. The Purpose and Administrative Organization of Branch Systems in Large Urban Libraries. M.A. thesis, University of Chicago.

Martínez-Ávila, Daniel. 2012. DDC-BISAC switching as a new case of reader-interest classification. Ph.D. dissertation, Universidad Carlos III de Madrid.

Martínez-Ávila, Daniel, Olson, Hope and Kipp, Margaret. 2012a. New roles and global agents in information organization in Spanish libraries. Knowledge organization 39: 125-36.

Martínez-Ávila, Daniel, Kipp, Margaret and Olson, Hope. 2012b. DDC or BISAC: the changing balance between corporations and public institutions. Knowledge organization 39: 309-19.

McCarthy, Austin. 1982. Burning issues: stock appeal in Sunderland. In Ainley, Patricia and Totterdell, Barry, eds., Alternative arrangement: new approaches to public libraries stock. London: Association of Assistant Librarians, pp. 88-100.

McClellan, Archibald William. 1973. The reader, the library and the book: selected papers 1949-1970. London: Clive Bingley.

McGrady, Amanda. 1990. Putting fiction back together. The unabashed librarian 76: 6.

Miller, Andrew. 1992. Alternative arrangement in Glasgow City Libraries. Public library journal 7 no. 5: 131-3.

Morson, Ian and Perry, Mike. 1982. Two-tier and total: stock arrangement in Brent. In Ainley, Patricia and Totterdell, Barry, eds., Alternative arrangement: new approaches to public libraries stock. London: Association of Assistant Librarians, pp. 101-18.

Nahl, Diane. 1996. The user-centered revolution: 19701995. In Kent, Allen, ed., Encyclopedia of microcomputers. New York: Marcel Dekker, Inc., pp. 143-99. Available http://www2.hawaii.edu/ nahl/articles/user/user1 to end_toc.html (Accessed 5 March, 2011).

Nahl, Diane. 2003. The user-centered revolution. In Drake, Miriam A., ed., Encyclopedia of library and infor- mation science, Second Edition. New York: Marcel Dekker; Inc., pp. 3028-42.

Olson, Hope A. 1997. Thinking professionals: teaching critical cataloging. Technical services quarterly 15 no. $1 / 2$ : 51-66.

Olson, Hope A. and Schlegl, Rose. 2001. Standardization, objectivity, and user focus: a meta-analysis of subject access critiques. Cataloging \& classification quarterly 32 no. 2: 61-80.

Ørvig, Mary. 1955. The reader interest arrangement, an American shelving system with future. Libri 5: 223-32.

Overington, Michael A. 1969. The Subject departmentalised public library. London: Library Association.

Paisley, Williams. 1968. Information needs and sses. $A n$ nual review of information science and technology 3: 1-30.

Pálsdóttir, Ágústa. 2010. The connection between purposive information seeking and information encountering: a study of Icelanders' health and lifestyle information seeking. Journal of documentation 66: 224-44.

Prytherch, Ray. 1990. Harrod's librarian's glossary of terms used in librarianship, documentation and the book crafts, $7^{\text {th }} \mathrm{ed}$. Worcester, U.K.: Gower.

Ranganathan, Shiyali Ramamrita. 1967. Prolegomena to library classification. Assisted by M.A. Gopinath $3^{\text {rd }}$ edition. Asia Publishing House.

Reader, Den. 1982. User orientation in a Heartfordshire Branch. In Ainley, Patricia and Totterdell, Barry, eds., Alternative arrangement: new approaches to public libraries stock. London: Association of Assistant Librarians, pp. 101-18.

Rutzen, Ruth. 1952. Shelving for readers. Library journal March 15: 478-82.

Rutzen, Ruth. 1959. A classification for the reader. In Eaton, Thelma and Strout, Donald E., eds., The role of classification in the modern American library. Champaign, Illinois: The Illini Union Bookstore.

Sapiie, Jacquelyn. 1995. Reader-interest classification: the user-friendly schemes. Cataloging \& classification quarterly 19 no. 3/4: 143-55.

Saricks, Joyce. 1997. A-leaving Cheyenne. Public libraries May/June: 154-5.

Saricks, Joyce. 2006. Thinking outside the genre and Dewey boxes. Booklist 102 no. 13: 64.

San Segundo, Rosa. 2004. A new conception of representation of knowledge. Knowledge organization 31: 106-11.

Satija, Mohinder Partap. 2004. A dictionary of knowledge organization. Amritsar: Guru Nanak Dev University.

Sawbridge, Lynn and Favret, Leo. 1982. The mechanics and the magic of declassification. Library association record 84: 385-6.

Scilken, Marvin H. 1998. Shelving genre fiction. The unabashed librarian 109: 9. 
Scott, Paul. 1995. Wheels within wheels genre fiction in public libraries. Australasian public libraries and information services 8: 191.

Sivulich, Kenneth G. 1989. Merchandising your library. Public libraries 28 no. 2: 97-100.

Sykes, Alan. 1982. Categorization or how Dewey gains a prefix and loses sanctity. Library association record 84: 383-4.

Taylor, John N. and Johnson, Ian M. 1973. Public libraries and their use. London: H.M.S.O.

Totterdell, Barry. 1978. Public library purpose: a reader. London: Clive Bingley.

Trotter, Ross. 1984. Dewey as an asset Catalogue and index 72 Spring: $1-4$.

Venter, Trude. 1984. 'n rangskikkingsmetode om die gegruik van nie-fiksie in openbare biblioteke te bevorder [An arrangement system to stimulate the use of nonfiction in public libraries]. South African journal for librarianship and information science 52(4) December: 110-2.

Wang, Amy B. 2009. Sun City Library embraces Deweyless world. The Arizona republic Sept. 9. Available http:// www.azcentral.com/community/westvalley/articles/20 09/09/09/20090909deweyless0909.html (Accessed 21 February, 2010).

Waples, Douglas. 1937. People and print. Chicago: University of Chicago.

Wijland, Hans Ban. 1985. Toegankelijker opstelling van informatie: di Duitse Dreigeteilte Bibliothek en de Britse alternative arrangement [A more accessible arrangement of information: the West German Tripartite Library and the British alternative arrangement]. Bibliotheek en samenleving 13(7/8) July/August: 133-238.

Wingett, Yvonne. 2007. Gilbert Library to be first to drop Dewey Decimal. The Arizona republic May 30. Available http://www.azcentral.com/arizonarepublic/local/articl es/0530nodewey0530.html (Accessed 24 February, 2010).

Woodford, Frank B. 1965. Parnassus on Main Street: a history of the Detroit Public Library. Detroit, MI: Wayne State University Press.

Zweizig, Douglas L. 1976. With our eye on the user: needed research for information and referral in the public library. Drexel library quarterly 12 no. 1/2: 48-58. 